\title{
Spatial cognition in landscape designations in the area of the Old European Hydronymy
}

1 Introduction

2 Old European Hydronymy

3 Analysis tools

3.1 Types of knowledge

3.2 Landscape designations

\author{
3.3 Semantic field of water designa- \\ tions \\ 3.4 Compounds \\ 4 Analysis \\ 5 Conclusion \\ 6 Bibliography
}

\begin{abstract}
Subject of the investigation are settlement names that refer to waters. These oikonyms are often the oldest. The research area is that of the Ancient European Hydronymy. The Old European hydronyms occur in Central Europe, in the Baltic region, in Southern Scandinavia, in the British Isles, in France, on the Iberian Peninsula and in Italy. The research question is, if the expression of spatial relationships in oikonyms with water words is a universal? It turns out to be also other naming strategies. The theoretical framework is Levinson's (2008) description of spatial cognition. The connection of spatial cognition with landscape terms is new in toponomastics.
\end{abstract}

Keywords: Ancient European Hydronymy, episodic-spatial knowledge, semantic-conceptual spatial knowledge, ideological knowledge, naming strategies

Schlagwörter: alteuropäische Hydronomie, episodisch-räumliches Wissen, semantisch-konzeptuelles räumliches Wissen, weltanschauliches Wissen, Benennungsstrategien

\section{Introduction}

The purpose is to clarify the status of spatial cognition with toponyms. Of the different types of toponyms mainly oikonyms or settlement names, if they relate to a special landscape condition, namely to waters, are treated. As The Oxford Handbook of Names and Naming says:

"[River names] can bear conditions in very remote ages, and naturally to early stages of language development (lexicon, phonology, morphology, and semantics). [These] names are considered the oldest and most enduring of all surviving place-names in Europe.” (Strandberg 2016)

\footnotetext{
Rosemarie Lühr, Humboldt University at Berlin, Institute for German language and Linguistics,
} Unter den Linden 6, D-10099 Berlin, e-mail: luehrros@hu-berlin.de 
Settlements along rivers and streams often offer the oldest names, too. Thus, the relationship between waters and people is dealt with. Our research question is the following: Is the expression of spatial relationships in oikonyms with water words a universal? If not: where are spatial references, where are they not? That's why the focus is on place names with a meaning transparent to speakers at the time of naming. ${ }^{1}$ The area to which the study refers is that of the Old European Hydronymy. The Old European hydronyms occur in Central Europe, in the Baltic region, in Southern Scandinavia, in the British Isles, in France, on the Iberian Peninsula and in Italy. The toponyms to be examined thus come from Celtic, Germanic, Baltic, Italic and Romance languages. Of the peoples who speak these languages, the Germanic and Romance speakers have immigrated into large parts of their historical settlements. In these areas, then new names will be made. In the other cases, the Celtic, Baltic languages and the languages of Italy before the Roman expansion, the corresponding speaker communities are already in situ at the beginning of the historical period. The investigation starts with the time of the first documented record of the respective toponym. For our corpus, older toponymic layers, and possibly late oikonyms and field names, are selected if they support interpretations of earlier toponyms. Reliable data bases for the oldest oikonyms do not exist.

At the beginning, some notes on the latest research in the field of ancient European hydronymia. This is necessary because the assumption of an Old European Hydronymy has long been the subject of lively discussions between advocates and opponents. Afterwards an overview of the theoretical framework which we follow is given. It is above all Levinson's description of spatial cognition. The connection of spatial cognition with landscape terms containing words for water follows. This is a new approach in toponomastics. ${ }^{2}$

\section{Old European Hydronymy}

The term “Old European” is used by Hans Krahe (1964) for the language of the oldest reconstructed stratum of the European hydronymy in Central and Western Europe. Krahe recognized that the naming of these waters was through the use of words or their derivatives that signified either the water itself or its characteristics, colors, different types of waters, or the manner of flowing. The formation elements used form a suffix system because they similarly recur fairly regularly among the various roots:

1 In other words: We are looking for the denomination motive of a language creative denominator.

2 The so-called "oriented" settlement names (Jochum-Godeglück 1995) are based on a completely different spatial concept. 

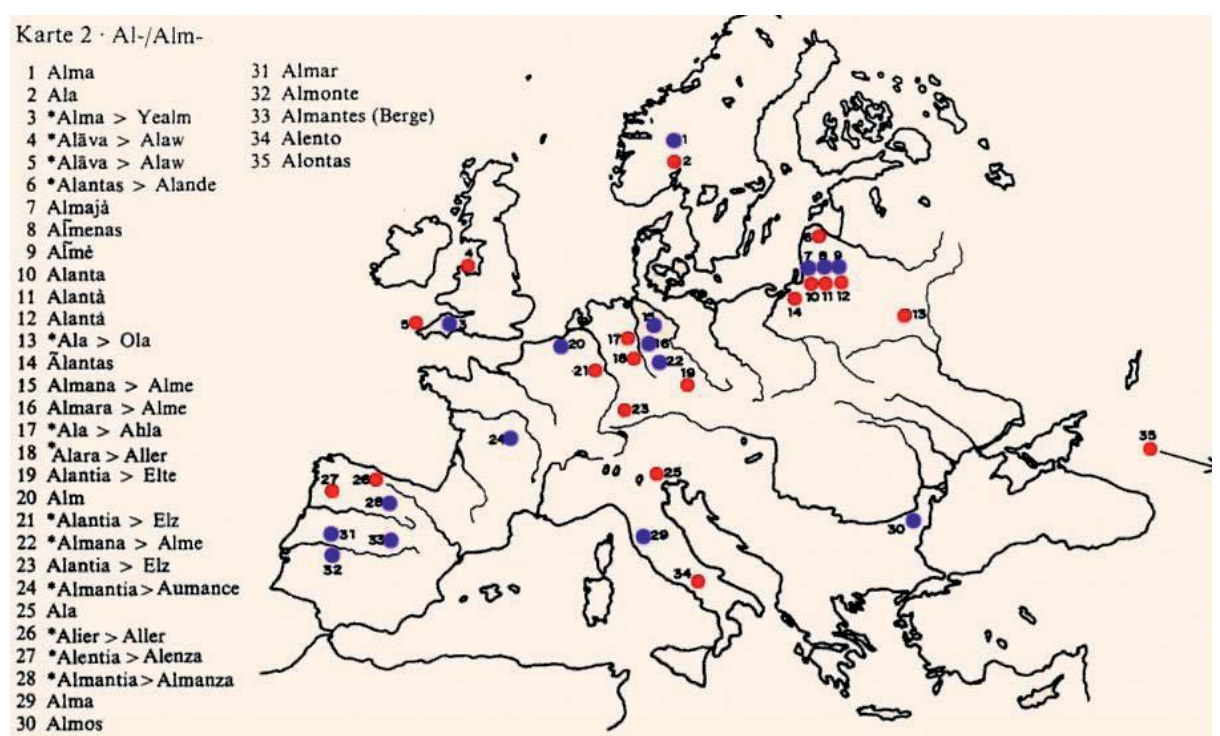

Figure 1: Author: Dageno: Español: Hidrónimos antiguos europeos: Carta para la raíz *al-, *alm (retrieved February 25, 2021, from https://commons.wikimedia.org/wiki/File:Old_European_ hydronymic_map_for_the_root_*al-,_*alm-_Krahe.jpg)

But the Old European Hydronymy can only be determined as Indo-European, if the word formation types in question are also to be found in the appellative vocabulary of the Indo-European languages; $\mathrm{cf}$.

river name Norwegian Ausunda < ${ }^{\star} h_{2} a ́ u s n t a \bar{a}(-n)$ - 'the bright one'; Italian Ausente (Proto-Indo-European ${ }^{\star} h_{2} u s$-ént-, Old Indic uṣânt- 'lighting up'); cf. Ancient Greek

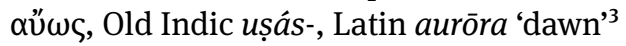

Unfortunately, since the time of Krahe the exploration of the associated water names has often been carried out with an unchanged methodology, which is completely outdated by the modern point of view of Indo-European linguistics. An Indo-Europeanist who submitted numerous publications on this unsatisfactory research situation is Harald Bichlmeier. In (2016) he shows, inter alia, based on the river name Elbe (Latin Albis) (Old Icelandic elfr 'river', Middle Low German elve 'riverbed') that the usual interpretation as ${ }^{\star} a l b^{h}-\bar{l} /-i \bar{a}$ adjective 'white' or noun 'the white one' is insufficient because the Indo-European preform ${ }^{\star} h_{2} e l b^{h}$ - or ${ }^{\star} h_{1}{ }^{*} h_{3} a l b^{h}$ - definitely contains an initial laryngal. The laryngeal theory states that the Proto-Indo-European language had three phonemes beyond those reconstructed ones. Laryngeals are notated as $h_{1} h_{2} h_{3}$. For the river name Albis, this means that also other approaches than the connection with a color word are possible. If one segments the underlying

3 Similar names are widespread in Europe, as Ausa, Ausava, Ausenna, Ausent-, Auser. Krahe (1963: 291) derived them from a 'water'-lexeme "^ $a w(e)$-” with $s$-extension and further suffixes. 
adjective ${ }^{\star} h_{2} e l b^{h}-O-/{ }^{\star} h_{1} /{ }^{\star} h_{3} a l b^{h}-O$ - as ${ }^{\star} h_{2} e l-/{ }^{\star} h_{1} /{ }^{*} h_{3} a l$ - and suffix - $b^{h} O-$, the reconstructions ${ }^{\star} h_{1}$ olh $h_{2}-b^{h} O$ - 'roving about' or ${ }^{\star} h_{1} o l-b^{h} o$ - 'maroon' ${ }^{\star} h_{1} o l(H)-b^{h} O$ - 'marshy, swampy' arise. But because of the shape of the originally unregulated river just in its lower reaches, which leads through largely flat, low-sloping terrain, or its way through the Elbsandsteingebirge, Bichlmeier considers the interpretation "meandering river" for the Elbe as the most likely. Thus, this river name is an example of the fact that the hypothesis of a pre-existing Old European Hydronymy can be confirmed with the help of modern Indo-European linguistics.

As far as the language of the Old European Hydronymy is concerned, Bichlmeier (2017: $41 \mathrm{f}$.) offers several scenarios for ranging it in the Indo-European languages of Europe. It is probable that the Old European Hydronymy language is a "reflex" of the precursors of Celtic, Germanic, etc. ${ }^{4}$. But further research is necessary.

\section{Analysis tools}

\subsection{Types of knowledge}

Spatial cognition concerns the study of knowledge and beliefs about spatial properties of objects and events in the world. It is a subfield of cognitive science. In the cognitive system, proper names and thus also toponyms represent one-place functional terms. They have an $s$ argument that relates to the reference situation (world / time / place index), and are inherently unique and definite (Löbner 1985). The speaker or viewer orientates himself in space and is always available as a deictic center, as a reference point. The position of reference objects must therefore always be easily recognizable to him ${ }^{5}$.

Object of spatial cognition research are two types of knowledge:

a) Episodic-spatial knowledge, the ability to remember experiences, occurrences, and events that happen at a given time in a given place (Tulving 1972) ${ }^{6}$

\footnotetext{
4 Bichelmeier (2015[2016]: 303f.) expects at least two waves of Indo-Germanization: one from which the hydronyms originated and another from which the later testified languages emerged, such as Celtic, Germanic, Baltic, Italian. Phonetic features of the language of the Old European Hydronymy include the coincidence of media and media aspirata in media, the coincidence of late Proto-Indo-European ${ }^{\star} O$ and ${ }^{\star} a$ in ${ }^{\star} a$, Kentum characteristics, etc. (Bichlmeier 2017: 43).

5 One speaks of topological localization when the self-structure of these objects is disregarded (Levinson 1996).

6 Cf. the terms "episode designations" in Nordistics and "event names" in field name research. If the concept of episodic memory is extended to a collective dimension, then such a commemoration refers to events that all participants have experienced together and which they retrieve together (Echterhoff 2004: 75).
} 
b) Semantic-conceptual spatial knowledge, the ability to store and remember information about the world in which we live, rather than concrete experiences (Knauff 1997: 2ff.)

c) Come in addition: ideological knowledge. Ideology is understood here as a system of worldviews, attitudes and values tied to a social group or culture.

On b) $\alpha$ ) Designation by subspaces: In typology research one distinguishes between an inner subspace, the marginal and the outer subspace with periphery (Becker 1994, Becker/Carroll 1997). But there is also an intermediate or Between-space. An example is:

$\mathrm{R}(\mathrm{x}, \mathrm{y})$ : The hut is between the hills

where $\mathrm{x}$ is the referent (the object to be located / locatum, via which a statement is made (hut), y the relatum, the reference object to which the statement is referenced (hills) and $\mathrm{R}$ the local relation (between) (Miller/Johnson-Laird 1976)

Cf. the following list of means to describe designations of subspaces:

Table 1: Prepositions, adverbs and adjectives for all the designations of subspaces (after Chuang 2010)

\begin{tabular}{llll}
\hline Subspace & prepositions & adverbs & adjectives \\
Indoor space & in; inside; within & inside & inner \\
Between-space & between & & middle \\
External space & outside & outside & outer \\
Margin space & by, at & & \\
\hline
\end{tabular}

On b) $\beta$ ) Designation by reference points: Other fundamental distinctions arise from the question of how a place can be located in relation to a reference point, a ground / relatum, so that someone finds that place. This approach was modified by Talmy (1983) according to figure (theme or trajector) ground (landmark) relations and applied to languages from five continents for the non-onomastic domain by Levinson/Wilkins (2006). The question is always, "Where is the figure?" the place to be located. The choice of a ground then depends on the extent to which it is permanently available. Levinson (1996; 2003; 2008; Levinson/Wilkins 2006: 515) gives the following scheme, which is adapted here to the spatial relations of toponyms: ${ }^{7}$

7 In Levinson's (2003) toponyms are ranked next to the category topology only under the first locative class, that is, those in which no reference to a coordinate is given. Also the concept of "deixis", as Levinson understands it (for example, "the place here") does not appear in toponyms. 


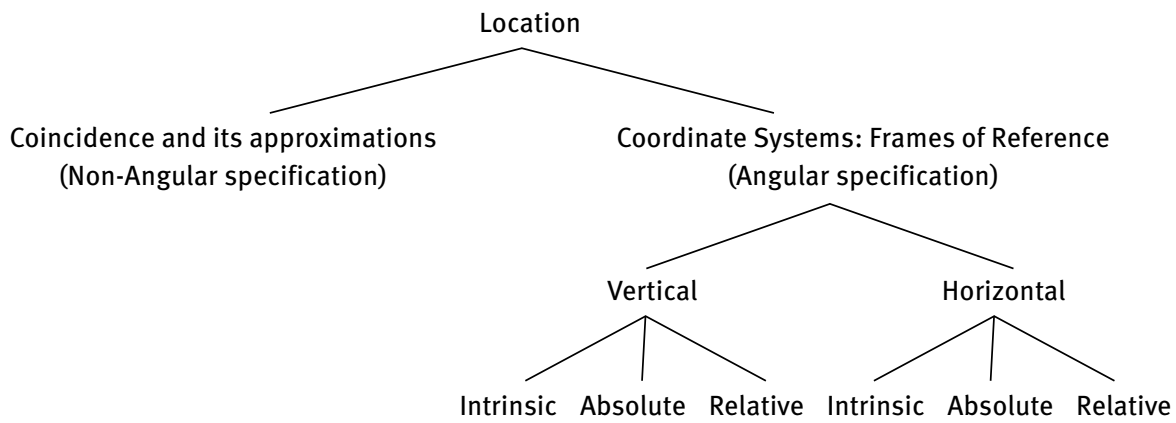

Scheme 1: Designations of reference points

Designation after approximation (left branch of the scheme): For toponyms, the deictic center may be (implicitly) identical with the relatum, for example, the location is close, this means: close to the viewer, thus signalizing a far-near concept (see "Coincidence and its approximations" in the scheme above).

Designation after a coordinate system (right branch of the scheme): Like other static space entities, toponyms can be localized according to a coordinate system with three straight lines, vertical, horizontal, and lateral, each pointing in two opposite directions. This theoretically results in six different coordinate-related subspaces, namely the upper, the lower, the front, the rear, the right and the left subspace. Decisive are the following three frames of reference:

i) Intrinsic frame of reference

ii) Relative (or deictic) frame of reference

iii) Absolute frame of reference

\subsection{Landscape designations}

First a brief note on water designations in general. Smith/Mark (1999; 2001; 2003) have attempted to relate to the folk theory of landforms, thus developing a naive ontology of landscape. As in their studies revealed, waters represent the most important geospatial concept. Non-expert English speaking subjects listed shape-based landforms in the following order (Smith/Mark 2001: 607):

Table 2: Landscapes

\begin{tabular}{lllllll}
\hline Mountain & River & Lake & Ocean & Valley & Hill & Plain \\
48 & 35 & 33 & 27 & 21 & 20 & 19 \\
Plateau & Desert & Volcano & Island & Forest & Stream & \\
17 & 14 & 10 & 8 & 6 & 6 & \\
\hline
\end{tabular}

Altogether 101 subjects voted for waters, 78 for hill and 40 for plain. 


\subsection{Semantic field of water designations}

The high number of votes for waters does not surprise, because it is due to the numerous different types of waters. Cf. the following Semantic Field:
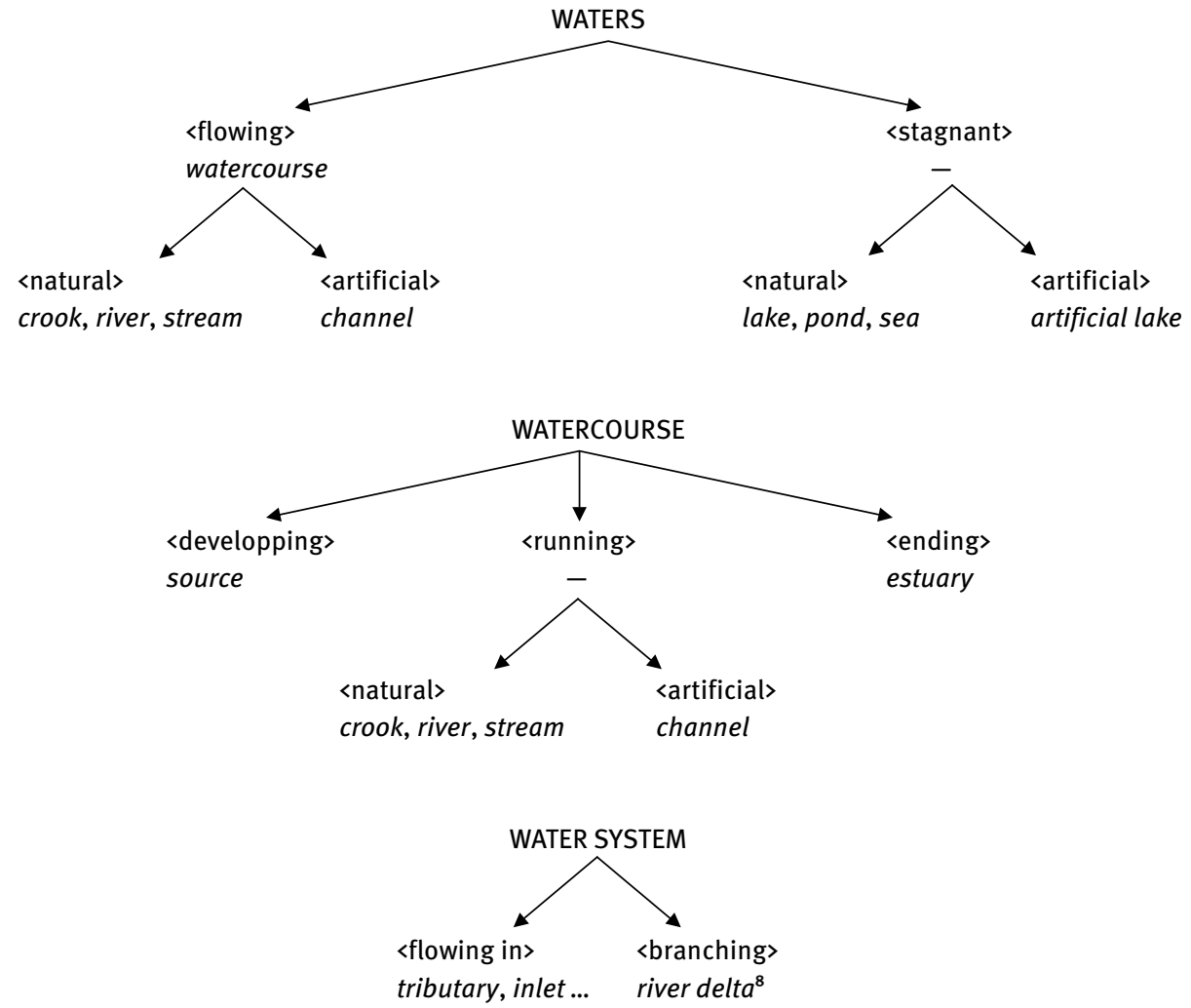

Scheme 2: Water designations (Susanne Zeilfelder: Deutsche Wortfeldetymologie in europäischem Kontext. Sächsische Akademie der Wissenschaften)

\subsection{Compounds}

Before starting the analysis, an overview of word formation is given: The toponyms can be assigned to different compound types. The following records originate from Swiss German online database “ortsnamen.ch”, that we use for comparison purposes:

8 According to the U.S. Geological Survey, there is no official difference between hills and mountains. Hills are easier to climb than mountains, they are less steep and not as high, but, like a mountain, a hill will usually have an obvious summit, which is its highest point, etc. 
Determinative compound (=D): Ausserfeld 'outer field'; determinative juxtaposition (= DJ): Inner Allmig 'common property located within'; determinative "head-form” (= DH): Mettlen < ${ }^{\star} z i$ dero mittilôno [marcho]: adjective gen.pl. mittel + elliptical appellative marka 'into [the area of the persons living] in the middle'; determinative "bracket-form" (= DB): Apfelberg 'apple mountain, terrain elevation with apple (trees)'; prepositional [complement] compound (= PC): Amsteg [Silenen] '[village] situated on the bridge [old crossing over the Chärscheler and the Reuss]), a type of exocentric compound in which the designated entity is not part of the designation (Lühr 2004) ${ }^{9}$. As we will see, the last composition type is by far the most common for oikonyms with water words. It is marked by "PC". Cf. also Romance documentary 1321 Flumnes '(location at the) river' (Chur; Kanton GR, CH) (lat. FLUMEN ,Fluss').

The outline is: Expressions recording semantic-conceptual spatial knowledge come first, then representations of episodic-spatial knowledge follow. Finally, oikonyms where spatial references are of secondary importance are discussed.

\section{Analysis}

\section{A. Semantic-conceptual spatial knowledge}

\section{A.a. Subspace: Between-space}

A prepositional (complement) compound is:

Celtic: Latin/Gaulish: 1180-1181 [Latin] (possibly later forgery) Interlacus, 1181 Interlacensis, [Gaulish] 1228 Indrellappa, Inderlappa ${ }^{10}, 1577$ Jn der lappen, 1891 Interlaken, (germanized) Undersewen, Unterseen '(location) between the seas' (Interlaken, $\mathrm{BE}, \mathrm{CH})(\mathrm{PC})$ - Interlaken is located in the Bernese Upperland between Lake Thun and Lake Brienz (Continental Celtic, Gaulish ${ }^{\star} l a p \bar{a}<{ }^{\star} l a k u \bar{a}$ - with ${ }^{\star} p<{ }^{\star} k u$ - as in Gaulish Epona < Proto-Celtic ${ }^{\star} E k u$-onā; Proto-Indo-European ${ }^{\star} l e g / g$ - 'to trickle' [EWA V, 876978; Bichlmeier 2009[2010]: 257-259; 2012: 379-390])

The same concept is encountered in:

Germanic: German: Unteraa '(location) between the water courses' (PC) (at the river Reuss) (Farm, Gurtnellen, UR, CH) [Old High German unter 'between'; Old High German aha 'water(course), river, stream', Middle High German ahe, Latin aqua 'water (pipe)'] (ortsnamen.ch/)

9 Quite a different kind is the Romance word formation, not only concerning the position of the individual elements (Rainer 1993: 246).

101239 de Inderlapon, 1239 in villa Inderlapen, 1266 Hinderlappun, 1300 Hinderlappen. 
The appellative aha appears only sporadically in dialects today. As designation of medium sized rivers, it appears e. g. in 752 Fuldaha. aha definitely designates flowing waters.

As for the designations of a margin space, all oikonyms with the intended meaning '(location) at a river, at a sea' would belong here.

Cf. the following prepositional (complement) compound with a designation of a precise location point:

Celtic: (Geograph von Ravenna) pennelocus '(station) at the top of Lake Geneva' (PC) (Old Irish cenn, Middle Welsh penn < Proto-Celtic ${ }^{\star} k^{w} e n n o-$ 'head'; nom.sg. *lokus, gen.sg. lakóu-s < ${ }^{\star} l k$-ou-s 'lake'; [Old High German lahha 'pool, puddle < Proto-Germanic *lakō)

Coincidentally, those oikonymys are terms after the absolute frame of reference.

They are therefore classified there. Oikonyms referring to waters for the other subspaces, Indoor space and External space, did not occur yet.

\section{B. Designation by reference points}

\section{B.a Designation after approximation}

A far-near concept can be found in the following oikonym:

Germanic: German: 1544 an die Ferenbachen; 1581 an die Ferenbacheren; 1611 obsich an die Ferabacheren 'distant (location) at the creeks' ('upwards to a distant [estate] near creeks' (DB) (Ferbacheren, secular building, Sattel, SZ, CH) (Swiss German fer(r), Old High German fer 'far, far away', Middle High German verre 'far away', in names for distant, remote places [ortsnamen.ch]). The oikonym is a determinative "bracket" form.

\section{B.b Designation after a coordinate system}

i) Intrinsic frame of reference of the relatum: the relatum has a spatial structure. For example, a church has a front and back. The description does not change when the entire constellation (figure and ground) is rotated on its own axis; it is independent of orientation (constancy under rotation). For this frame of reference no oikonyms with water words were to be found. ${ }^{11}$

11 See Lehmanns (2019) example for a location in Erfurt: St. Severi is on the left side (the triangle side) of the cathedral. The intrinsic frame of reference aims at the dimensional structure of the relatum, here the cathedaral. Oikonyms with an intrinsic frame of reference would be names such as '(location) behind the back of the church (but in front of the viewer's location)'. Cases like Swiss German Hinter dem Chäppeli '(location) behind the Chäppeli' (Bärschwil; Kanton SO, CH) are not relevant. For free areas in the vicinity of churches are either used as a cemetery or in the widest sense as agricultural land, which are then usually associated with the vicarage (material preservation of the parish), called 
ii) Relative (or deictic) frame of reference: the starting point in the coordinate system, the viewer (origin), the figure, and the ground are each different, with the viewer's system mapped to that of the ground object in a kind of secondary coordinate system. The description is thus based on the intrinsic system of the viewer. He sees himself as a structured object with front and back, top and bottom, right and left side. As the figure and ground constellation rotates about their own axis, the description changes. It is orientation-dependent.

The settlement history shows, that mainly flat, fertile valleys are populated in river valleys. Moors, forests and mountains, on the other hand, are often considered as divisive, hard to cross terrain forms, so that a view 'from our settlement in front of the forest or behind the moor' is understandable; cf. the following Baltic oikonym:

Baltic: Lithuanian 1584 Uszballen(n) '(locality) behind the moor' (PC) (Ǔžbaliai, Darkehmen, East Prussia) (Użbale, Gołdap, Poland) (Lithuanian balà 'moor'; prefix $u \check{z}$ - 'behind' [Pètraitis 1997: 421]). It is a prepositional [complement] compound.

iii) Absolute frame of reference: When referring to an absolute frame of reference, the speaker chooses a fixed point of reference independent of any particular situation, such as cardinal points, landscapes as mountains, rivers. The description is also orientation-dependent here. It changes when the entire constellation is rotated around its own axis. In this frame of reference, the ability to orientate in absolute space is a prerequisite. For example, the viewer needs to know where is upstream and downstream.

In Western populations, this reference type is most prevalent in oikonyms. Therefore, there is a lot of literature, even though often exact reference assignments are missing. Nevertheless, we provide examples to show that the absolute frame of reference is also present among the oldest oikonyms within the area of Old European Hydronymy.

A cardinal point is indicated in:

Germanic: Old High German: 1157-1163 Westense, 1157-1163 ... de Westeses (Bad Wiessee, Miesbach) 'on the western shore of the (Tegern-) lake (located settlement' (PC) (Old High German westan 'westward'; ahd. sē [Reitzenstein, Bayer. ON, 30])

In the case of the orientation to the vertical relation with the concepts 'upper' and 'below' the human body is the reference point, namely the head-foot axis. At the same time, however, there is above, where the sky, and below, where the earth is, and thus an absolute frame of reference within the coordinate system is given.

A designation after the head-foot axis is:

Celtic: 1163 Veronne, 1201 castrum de Verona, $14^{\text {th }}$ c. prioratus de Verona, to designate the river Rieusset that flows down from above: '(location) at the Véronne'

Pfarrgründe ‘Pastor’s Property’ or Pfoargründ (Fritz Locher von Hüttenbach/Erika Windberger-Heidenkummer orally). 
(PC) (Véronne, commune, Département Drôme); river name *ueronā < Proto-Celtic

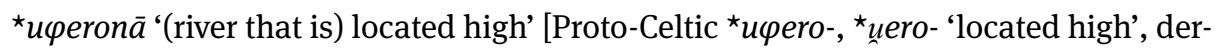

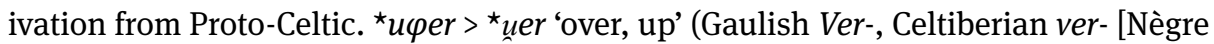
1990: 46; Schaffner 2015: 249])

The river has a height of 87 meters:

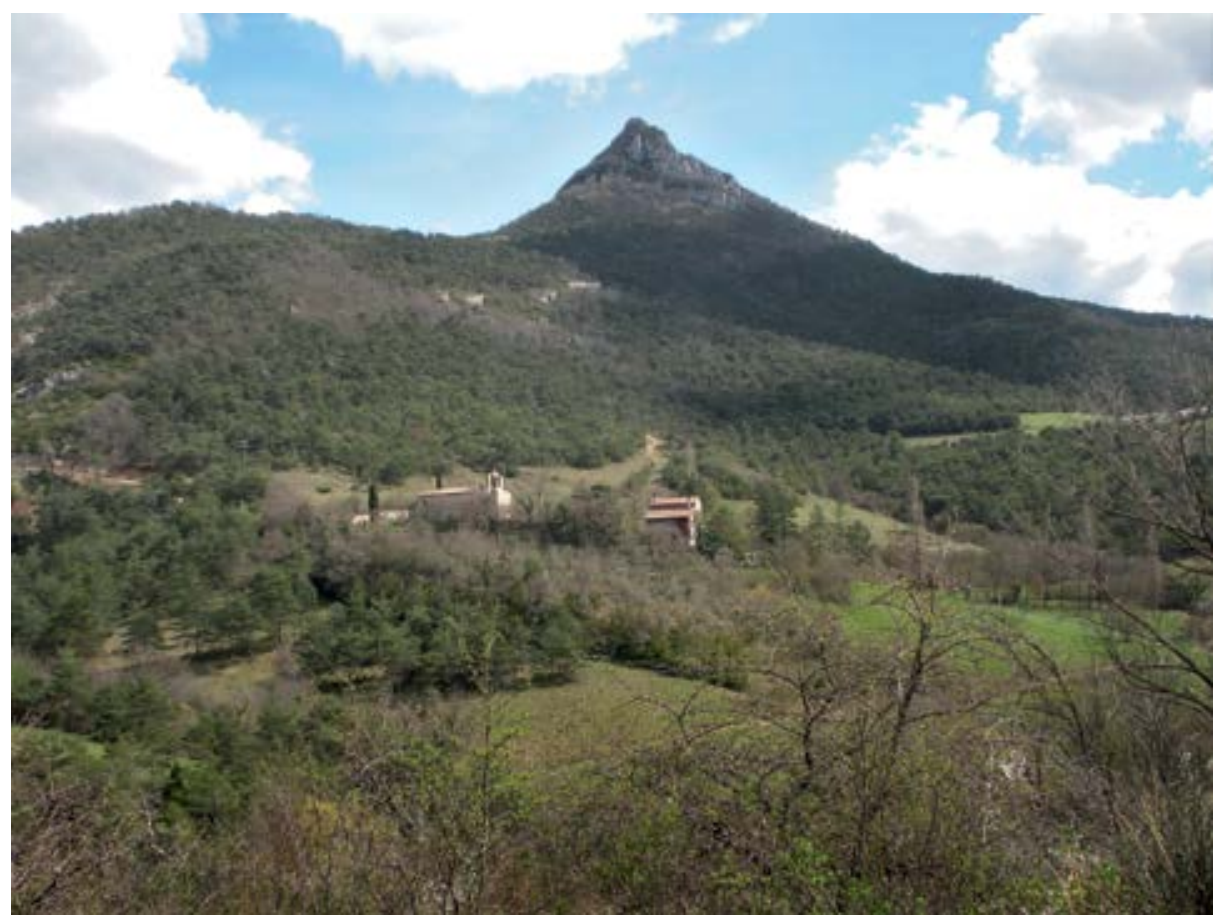

Figure 2: Author: Toutaitanous 2: Veronne le haut (retrieved February 25, 2021, from https:// commons.wikimedia.org/wiki/File:\%C3\%89glise_de_Veronne_(dr\%C3\%B4me).JPG)

The oikonym is a prepositional (complement) compound, the river name a determinative "head-form"; it shows a specifiction. Indeed, river names are particularly enlightening if they contain specifying additions: for specifications may allow conclusions not only about topographical features or economic forms, but also on the range of movement of former settlers. For example, more specific hydronyms may indicate that the first denominators had knowledge about other rivers in their environment, from which they wanted to distinguish their river in their place. So to speak, that they must have been "mobile".

For the oldest river names, however, the specification must be reconstructed. An ancient water word is continued in: 
Baltic: Old Prussian 1440 Kirsappen '(location) at the river (later on a dammed up pond)' (PC) (Kirschappen, Fischhausen, East Prussia) (Old Prussian kirsa 'above, on'; Old Prussian ape 'river' [Gerullis 1922: 64; Blažienė 2006: 311])

The oikonym contains the inherited word for 'water'; cf. Hittite hapa- c. 'river', Old Indic nom.pl. à pas 'water, stream', Tocharian āp- 'water, river', Lithuanian ùpé, up ̃̃ 'river, stream, creek', Latvian upe 'river, creek' (with late sound change from * $a$ to Proto-East Baltic $u$ - [ALEW II, 1156] < Proto-Indo-European ${ }^{\star} h_{2} a p$ - < ${ }^{\star} h_{2} e p$ - 'water'). Special properties of the water are not specified in this word. But obviously it refers to running water.

The Proto-Indo-European root appears also in:

Old European: 1138 (copy 12. c.) Habensperch, 1143 Abensberg (Roman station name $3^{\text {th }}$ c. [copy $7^{\text {th }} / 8^{\text {th }} c$.] '(settlement) on the river Abens' (PC) with -berg by reference to the castle, the seat of the lords of the Babons (Abensberg, Kelheim, BY, D); river name 847-863 Apansa [derivation of Proto-Celtic ${ }^{\star} a b o n-;$ nom.sg.f. ${ }^{\star} a b \bar{u}$, gen. ${ }^{\star} a b o n s$ $<^{\star} a b h_{3}$ ens, acc. $\left.{ }^{\star} a b o n a m\right]$ (Old Irish aub, gen. abae 'river', Old Cornish auon, Middle Welsh, Middle Breton avon 'river'; France Côte d’Or 1174 Avonna); Proto-Germanic ^berga- 'mountain' (Reitzenstein, Bayer. ON 7). One of the ways to combine Proto-Celtic ${ }^{\star} a b o n$ - with the just mentioned Proto-Indo-European ${ }^{\star} h_{2} a p$ - 'river' is the assumption of a derivative with a possessive suffix ${ }^{\star} h_{3}$ on- whereby laryngeal 3 lenites the preceding voiceless plosive ${ }^{\star} p$ to ${ }^{\star} b .^{12}$ In this case the meaning of Proto-Celtic *abon- would be '(river) that carries running water'; cf. High German, Low German -affa, -apa < Proto-Germanic *apō, Latvian Abava (Hoffmann 1957; Schaffner 2015: 233-237, 244-246)

A second Proto-Indo-European water word is documented in:

Baltic: Old Prussian 1285 Powunden, 1397 Pawonden (Prussian Holland; today Powodowo, Richliki) '(location) nearby the water' (PC) (Lithuanian pavandené 'area nearby the water')

(Old Prussian po 'nearby'; Old Prussian wundan 'water'; Latvian ûdèns; Lithuanian vanduõ 'water' [Gerullis 1922: 133]; $n$-stem with ablaut; from a nasal-present Proto-Indo-European * $u$ - $n$-éd-in Vedic unátti; Proto-Indo-European acrodynamic $r / n$ stem nom.sg. *uodr in Hittite wātar; Old High German wazzar, gen.sg. *ᄎ uéd-n-s $\rightarrow$ *ued-én-s in Hittite gen.sg. wedenas; cf. Gothic watins); Proto-Indo-European *ued- 'to swell' [ALEW II, $1185 \mathrm{f}$.; LIV 658f.])

If the underlying verbal root really had the meaning 'to swell', the ancient water word could have originally referred to spring water; cf. the derivations Vedic útsa-

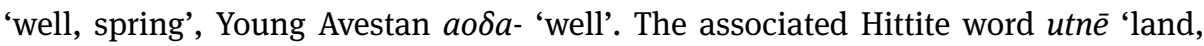
country' also indicates this meaning. The supposed development of meaning from 'watery, hydrous' to 'fertile' to 'land' could have started from 'rich in wells'; cf. Arme-

12 Cf. the Old Indic reduplicative verb pibati 'drinks' < * $p i-p_{3}$-eti from Proto-Indo-European ${ }^{\star} p{ }^{2} h_{3}$ 'drink' (for further explanations cf. Bichlmeier 2009: 197-201). 
nian get 'river' and the derivation, the landscape term getin 'soil, ground' (NIL 706715).

While the Old Indo-European words for water seem to represent a more general idea of it, insofar as special meanings have to be deduced, the orientation according to distinctive characteristics of waters is common in the area of Old European Hydronymy.

The watercourse is specified in more detail in:

Celtic: Cambous, Cambon '(location) at the river bend' (PC) (Chambon / Cambon, Loiret FR) (`kambonos; Proto-Celtic ${ }^{\star} k a m b o$ - 'bent, crooked, curved')

Celtic: 1012-1018 (to 977) Camma, ca 1040 Champa (Cham, BY, G) (river name 1058 $\mathrm{Kamb}$ ). A few kilometers from the city Cham, a winding brook, called the Chamb, flows into the Regen.

A similar concept appears in:

Celtic: 1309 (copy 1385) in superioi Sinne, ca. 1319 in Obernsinn ... in Mettelnsinne '(location) at the upper / middle Sinn' (PC) (Obersinn, District Main-Spessart, Lower Franconia, G); river name Old High German 780-796 (copy $12^{\text {th }}$ c.) Sinna, 1328/29 Sinne (copy $14^{\text {th }}$ c.) Sinne < Proto-Celtic * $\sin -n-i i \bar{a}$ ( ${ }^{\star}$ sino- $n-$, ${ }^{\star} \operatorname{sinn}$-); Italian Senio tributary of the Po, Tabula Peutingeriana Sinnius (< ${ }^{\star}$ Sinn-ios). The etymology points to the original

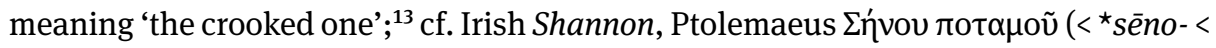
* seino- 'the crooked, bumpy one' ('the one who is provided with bays') ${ }^{14}$ (Latin sinus, -ùs 'bay, bending, curve, fold, bosom, lap, curved or bent surface' [Schaffner 2015: 237-240]). The term ober- 'upper' means the location of the settlements and not that of the rivers. ${ }^{15}$

The following oikonym belongs to the semantic field 'swampy terrain'. It is common to Celts, Germanics and Balts: ${ }^{16}$

Celtic/Old High German: landscape name $9^{\text {th }}$ c. pagus Onfelt, 1217 Onvelde, 1418 Kirchohmfelde (with assimilation of - nf- to -mf-), 1545 warmen Omfelt, 1596 Warm-Ohmfeld, Kirchohmfeld (Eichsfeld, Thuringia) '(location) at the Ohmfeld with a church', a determinative and coincidentally prepositional (complement) compound; landscape name c. 1518 Kalten Ohmfelde, 1530 Kalt Ohmfeld (on the highest elevation of the Ohm Mountains) (Kaltohmfeld, District of Leinefelde-Orbis, Eichsfeld, G) (Dobenecker, Wintzingeroda-Knorr) (Gaulish gloss anam 'paludem' [Delamarre 2003: 43f.]; Old Irish an, $o$ - or $\bar{a}$-stem 'water' < Proto-Celtic * $\varphi$ ano- or * $\varphi a n \bar{a}$ 'something damp, watery' [EDPC 127]; Proto-Celtic * $\varphi$ ana '(something) wet, watery', collective formation to Proto-Celtic * $\varphi$ eno- 'water, river': Austrian river name Enos 'Inn' [Bichlmeier 2009[2010]:

13 Another basis form could be Proto Germanic *senP-nō- 'meandering (river)'; Proto-Indo-European *sent- 'to go' (Bichlmeier 2009: 83-84; 2015; Reitzenstein, Fränk. ON, 171).

$147^{\text {th }}$ c. gen.sg. Sinone, acc.sg. (latinized) sinonam < * sinona $\mathrm{f}$. < Proto-Celtic acc.sg. * sino-n-am f.

15 The Middle High German adjective ober 'upper' refers to the location of the place and serves to distinguish the Market Burgsinn and the parish village Mittelsinn in the same administrative district. 16 Sergio Neri has worked out this etymology. 
$34 \mathrm{f}$.$] ; Middle Irish en m. o$-stem 'water'; river name Inn < * enio- < * $\varphi$ en-i ${ }_{-1}{ }^{-17}$; Middle Irish enach, n. s-stem 'swamp' < * $\varphi e n \bar{a}-k o-s$ 'aqueous, moist area' [EDPC 127])

Kirchohmfeld is located on the southwestern edge of the plateau of the Ohmgebirge 'Ohm mountains'. Nearby is the Ochsensumpf 'ox swamp'. It is therefore actually a swampy terrain and the Ohm Mountains are named after it.

Baltic: Old Prussian: 1267 Panyen, 1339 Panyn, 1405 Pangen, 1422 Panygen, $14^{\text {th }} \mathrm{C}$. Katpanye; Old Prussin pannean 'mosebruch' '(locality) at the moss brook' (PC) (Pangessen, Memel, East Prussia) ([Sommerfeld 1971: 144]; Eastern Lithuanian pania-bùde 'forest mushroom growing in damp places'; Latvian pane 'liquid manure, dung-water' < Proto-Baltic * pan-i $\bar{a}$; peoples’ name חóvvoves, probably *'inhabitants of a damp area'< nom.pl.m. pannōnes)

Celtic: Germanic: Late Old High German: 1197 Venirode '(locality) at the swamp'

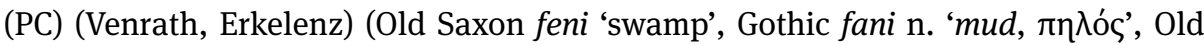
Icelandic fen n., Old English fen(n) m./n., Old Saxon fen(n)i, Old Frisian fen(n)e m., Old High German fenni n. 'swamp, bog, mud' ; Proto-Germanic *fanja-; from this the Romance loan words French fagne, fange, Italian fango 'mud'; Proto-Indo-European *pón-io- 'watery, wet area'18)

Quite another concept can be detected in:

Old European: Celtic: Ammerbuch '(location) at the Ammer' (PC) (Tübingen, D); ${ }^{19}$ river name Ammer (near Lustnau, Tübingen city), Amper (mouth into the Ammersee) (Proto-Celtic *ambarā / *ambrā f. < ${ }^{\star} m b^{h} r$-eh ${ }_{2}{ }^{*}{ }^{\star}{ }_{n} b^{h} r-e h_{2}$; German Emmer, English Amber, French Ambre, Italian Ambria, Ambrio < Proto-Celtic *ambriiīa ; Proto-Indo-European ${ }^{\star} n e b^{h}$ - 'to get wet' [Bichlmeier 2014[2016]; 2018: 9-12])

While the Ammer at Tübingen is described as flowing smoothly, the Ammer and its upper run (the Linder) in the Bavarian Alpine foothills are different. They are wild rivers. They flow from their source in the Ammergebirge 'Ammer Mountains' into the Ammersee near Fischen. ${ }^{20}$ In this case, the connection with the related words Vedic nabhanú-, nabhan $\overline{\text { - ' }}$ 'wild water, spring water' is close (NIL 500).

The name of a noisy rushing water shows up in the oikonym:

Germanic: German: Diesselbach '(location) at the Diesselbach ['roaring creek']' (PC) (hamlet, Mogelsberg, SG, CH) (Middle High German diezen 'to sound loud, rush', Old High German diozan 'to rush, roar' < Proto-German onomatopoetic *Peuta- [EWA II, 688-690; ortsnamen.ch])

17 Urkelt. ${ }^{\star} \varphi e n o-<$ thematic nominalized adjective Proto-Indoeuropean ${ }^{\star}$ pén-o- 'damp’ with ${ }^{\star} \varphi o n \bar{a}$ as abstract collective (EWA 3, 614 f.; Katz 2003, 86f.).

18 Casaretto (2004: 133); EWA (3, 152-154); cf. (with ablaut) Old English ae. fyne m./n. 'humidity, morass' $<$ Proto-Germanic * funja- < Proto-Indo-European ${ }^{*} p n-i o-$

19 The name Ammerbuch has not grown historically, but is an artificial word, which should refer to the location between Ammertal and Schönbuch.

20 Below the Ammersee the Ammer becomes the Amper, which flows at Moosburg into the Isar. 


\section{Similar:}

Celtic: c. 1050 Labare, 1180 Labara, 1186 Laber, 1712 Laaber '(location) at the Laaber' (PC) (Market, District Regensburg, BY, G); river name ca. 1150 (copy 14 ${ }^{\text {th }} \mathrm{c}$.) Labere, Schwarze Laaber, tributary of the Danube (Proto-Celtic *labarā 'the talkative, rushing one'; Old Irish labar 'talkative' < *labaro-, Welsh llafar 'speech, language, voice’ [García Alonso 2001: 220; Schaffner 2015: 248; Reitzenstein, Bayer. ON 148]) ${ }^{21}$

The opposite concept is expressed in:

Germanic: Middle High German: ca 1144 Tumbach, 1181 ... in Dumbac ... in superiori Dumbac (PK) '(location at the) silent creek' (PC) (Kirchenthumbach, Neustadt at Waldnaab, Upper Palatinate, G) - the differentiation superiori refers to the location of the river upstream of today's hamlet Stegthumbach (Middle High German tumb 'silent' [Reitzenstein, Bayer. ON, 137]) The Tumbach is today a fishing ground for fish species such as eel, carp, perch, zander. The carp prefers quiet and spacious waters, slowly flowing rivers or streams. Also zander or perch usually stay in the quiet sections of rivers.

Oikonyms with water terms also provide insights for phylogeography. Thus, plant names appear in oikonyms with water words:

Celtic: Darwen '(location on a river) where oak trees grow' (PC) (Darwen, Lancashire, GB) ( ${ }^{\star}$ deruentiiūu, deruentiion-; *deruent- 'oak', -nt-extension of *deruo- 'oak'). The River Darwen is running through the town Darwen; cf. 1217 Derventum (Drevant, Cher, Fr) '(location), where oak trees grow' (Mills 1991; Schaffner 2015: 249f.)

Celtic: 1217 fons Alsonae '(location) where alders grow' (PC) (Alzonne, Aude, Fr) ( ${ }^{\star}$ alsionā; Proto-Celtic ${ }^{\star}$ alis $\bar{a}$ 'alder’ + suffix -onā; cf. Old High German elira < Proto-Germanic * alis/zō ‘alder'; ${ }^{\star} h_{1 / 3}$ alis- $a h_{2}$ 'white tree' or ${ }^{\star} h_{1} e l i s-a h_{2}$ 'red tree')

Celtic: Leven '(localization) at the elm river' (Celtic *limonā; Gaulish *limo-, ${ }_{-}$ lemo-, Proto-Celtic *limo- 'elm', for example in people’s name Gaulish Lemo-vices, Limoges); village in the Scottish Council Area Fife. In Leven the river Leven flows into the Firth of Forth.

There are also water names with words for animals living at the water:

Celtic: Gaulish-Latin Bebriacum locus castorum (Tac. hist. 2, 23 Bedriacum; Iuv. 2,106 Bebriacum), Bibracte '(location) at a water where beavers are living' (PC) (SaintLéger-sous-Beuvray, Saône-et-Loire, Fr) (Proto-Celtic *bebru- 'beaver' + suffix *akti[Lambert 1994: 84]; Old Irish PN Bibar; Old Breton beuer gl. castor (?) or from vulgar Latin biber; see Old French bievre; Old Spanish befre)

Germanic: Old High German 762 Biberussa (copy 17. c.), 1251 de Bubrusche (Biberist, SO, CH) (Old High German bibar + suffix -ussa; Latin fiber; Old Saxon bißar, Old English beofer, Old Norse bjórr; Old Lithuanian bebrùs 'beaver' < Proto-Indo-European ${ }^{\star} b^{h} e b^{h} r u$ - [EDPG 56 f.; EWA II, 6-8])

21 Cf. further Bichlmeier (2016a: 8), but Proto-Indo-European root * $l e h_{2} p$ - 'to shine, be bright'. 
Germanic: Old High German: 715 Bibaraha (Biberach, District of Heilbronn, BY, D)

Old Low German: 786 Biuerna

Celtic: Teissonière (hamlet, La Motte-Servolex, Savoie, FR) '(location) at the

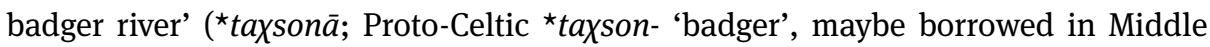
Latin taxō-, -ōnis > French tasisson, Italian tasso, Spanish tejon [Gros 1935: 464; Schaffner 2015: 251])

In addition to the designation of water features, there are categories that are formed according to their "affordance character" or according to the restrictions they impose on human activities.

Rivers are useful to humans if they are rich in fish:

Celtic: ca. 1309 (copy 1358) ... iuxta nouam citiuitatem apud Eisch 'settlement at the fish-rich (river)' (DC) (Neustadt a. d. Aisch, District Neustadt an der AischBad Windsheim, Middle Franconia, D); river name $9^{\text {th }}$ c. (copy $12^{\text {th }}$ c.) Eisga, Eisge 'the fish-rich one' (Welsh river name Wysg < Proto-Celtic ${ }^{\star} f e \bar{s} k \bar{a}<$ Vrddhi formation ${ }^{\star}$ peiksk̂̄ä; cf. Latin piscis 'fish'; Old High German fisc [however Reitzenstein, Fränk. ON 20, 160; Greule, Deutsches Gewässernamenbuch 28: "gm. ^Aiskō 'die Helle, Klare"'])

A river invites you to be crossed: Often there are oikonyms with a word for 'bridge' or 'ford':

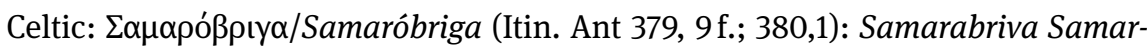
obriva '(location) on the bridge on the Somme'22 (Celtic Samara 'Somme'; Celtic briva 'bridge') $)^{23}$

Celtic: Germanic: Old English: c. 745 Grontabricc, Grantebrycge '(location) at the bridge on the River Granta' (PC) (a Celtic river name, of obscure origin) (Cambridge, GB). The change to Cante- and later Cam- was due to Norman influence. The river name Cam 'the crooked one' is a back-formation. One of the two tributaries of the River Cam still bears the name Granta.

Celtic: Camboritum '(place) located near the ford at the bend of the river' (PC) (Chambord, Department Loir-et-Cher, FR) (Proto-Celtc ${ }^{\star} k a m b o-$ 'crooked, twisted'; Proto-Celtic *ritum 'ford'). ${ }^{24}$

A watercourse with a natural bed of water is probably laid out in its course or channel-like expanded:

Celtic: Gaulish: 1219 Byey, 1241 Biez dessous Chastoillon, 1417 Bye, 1520 Biy '(location nearby a) channel' (PC) (Bief, Doubs, Bourgogne-Franche-Comté, F) (French bief 'channel' < Proto-Celtic *bedo- 'ditch, channel', Middle Welsh bedd, Pl. beddau,

22 No evidence of a preceding Celtic settlement has been found.

23 The Ambians settled on the Samara. Their capital, Samarabriva (Ptolemy II 9, 4), is later called Ambiani (Amiens) (Itin. Ant. 362. Ammian. Marc. XV 11, 10) (Amiens, Department Somme, region Hautsde-France, FR) (Latin Ambianum from [ad] Ambiānōs 'with the Ambians').

24 The village lies on the left bank of the Cosson River, east of Blois. 
beddi, Middle Breton bez, korn. beth 'grave'; Proto-Indo-European * $b^{h} e d^{h}$ - 'to dig' [LIV 66; EDPC 59f.; Nègre 1959: $130 \mathrm{f}$.])

The following oikonym comes from agriculture:

Germanic: Old High German: 1062-1066 Ohsnofurt. 833 (839) Ohsonsofurt 'ford of the oxen' '(Small) Ochsenfurt south of Würzburg' (G)

Germanic: Old English: 912 Oxnaford, ca. 1000 Oxenaford (Oxford, Oxfordshire, GB)

The name is of interest because it has an ancient genitive plural; cf. Gothic gen.pl. aushne (Wagner 2008: 167-169).

From their environment people gain energy, hydropower:

Celtic: Brythonic-Latin: 30 BC-AD 640 Braboniacum, Brauniacum (copy), Bravniacum, Bravoniacum [Britannia Romana 410] '(camp near a river) with a mill' (PC) (Kirkby Thore, Eden, Cumbria, GB). The village is on the site of the Roman cavalry camp. Nearby flows the river Eden (Old Irish brao, bra; Middle Welsh breuan; Middle Bretonic breo; Old Cornic brou gl. mola < Proto-Celtic ^brauon- 'quem, millstone' < Proto-Indo-European ${ }^{\star} g^{w} r e ́ h_{2}(u) o n-,{ }^{\star} g^{w} r h_{2}(u)$ nés-; Old Indic gràvvan-; Gothic -qairnus; Lithuanian girnos; aksl. žbrny) [Sims-Williams 2006: 49; EDPC 75])

Germanic: Old Saxon: 1276 Cornethe '(location) with a water mill' (PC) (Köhren bei Harpstedt, Oldenburg) (Old Saxon quern 'mill'; suffix -ithi- [Udolph 1991: 105]). Via Harpstedt runs the river Delme.

Such oikonyms show a pragmatic approach of humans with their environment. So far, oikonyms with words for water features and affordances in dealing with waters have been discussed, widespreac oikonyms in the area of Old European Hydronymy, which constantly re-emerge.

\section{B. Episodic-spatial knowledge}

Episodic-spatial knowledge comes into play in the worship of the gods on waters. In the analysis, the Celtic suffix -ona is decisive. ${ }^{25}$ Names of goddesses formed with this suffix are Gaulish Eponā 'Goddess of the horses' (Gaulish epo- 'horse'), Gaulish Nemetona 'Goddess of the sacred groves' (Gaulish nemeton 'holy grove'), Damonā 'Goddess of the deer' ( ${ }^{\star}$ damo-; cf. Old Irish dam 'deer, ox'). Thus, Delamarre (2012: 313-315) would like to explain almost all of the nouns on the suffix -on- or -ona as derivatives of Celtic deity names. However, as Schaffner (2015: 252-254) shows, of the 60 detheonymic Old Celtic place names in -on- or -ona , which Delamarre postulated, only fifteen cases testify a deity name as a possible derivation basis. In his opinion, only the following river name belongs to the formation type Epona a, namely the name for the Marne:

25 This suffix appears also in ${ }^{\star}$ tax sonā or ${ }^{\star}$ limonā. 
Celtic: Matrona 'The great mother goddess' (Middle Welsh Modron), Marne (Départments

Haute-Marne, Marne, Seine-et-Marne and Val-de-Marne) ${ }^{26}$

After Caesar, this river formed together with the underflow of the Seine the border between the proper Gaul and the settlement area of the Belgians. The worship of a goddess of the same name is testified in a dedicatory inscription, which was found in 1831 in the headwaters of the Marne, not far from the city of Langres (Maier 1994: 227-228). It is to be assumed that Matrona was worshiped in this place.

Another goddess name is the Gaulish name of the Seine, Sequana. The name of the river is based on an eponymous goddess named Sequana, whose worship is evident from numerous archaeological finds from pre-Roman and Roman times as well as from several inscriptions (Maier 1994: 289).

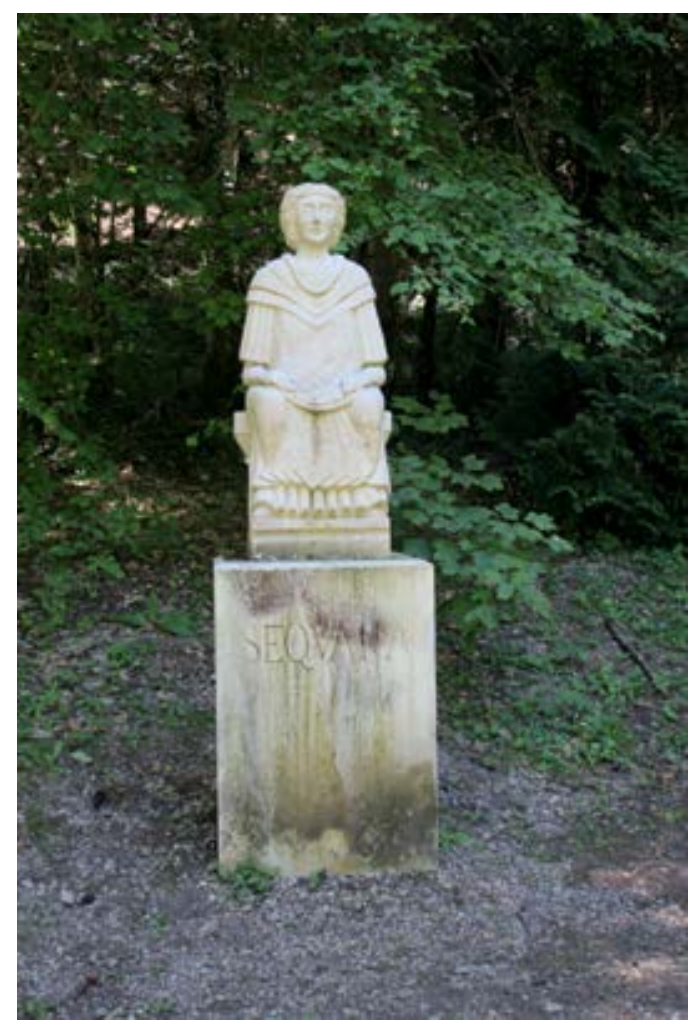

Figure 3: Author: Adrian Michael: Sequana statue at the source of the Seine in Source-Seine (French commune Département Côte-d'Or in the region Bourgogne-Franche-Comté) (retrieved February 25, 2021, from https://commons.wikimedia.org/wiki/ File:Sequana_D\%C3\%A9esse.jpg)

26 The Marne flows at Charenton-le-Pont, just southeast of Paris, as a right tributary into the Seine. 
According to Lacroix (2007) waters have constituted for the Gaulish peoples a privileged support of religion. They were sacralized more than any other element of the nature and engendered more devotions than terrestrial entities. Indeed, the whole point may be that in the prehistoric period, when the waters were named, one can confidently count on a type of sacral status of natural phenomena, even if this is not more than 1000 years later indicated by a Roman inscription. Also in Celtiberia such sacrifices must have been practiced, but little can be said about them in detail. ${ }^{27}$

In addition to the spatial dimension, worship also has a temporal dimension. Thus, place names can also refer to episodic-spatial knowledge.

\section{Ideological knowledge}

While the goddesess Matrona and Sequana can be allocated to veneration sites near the eponymous rivers as a result of archaeological finds, the following place names originating from Celtiberian behave differently. The Celtiberians inhabiting the central-eastern Iberian Peninsula during the final centuries BC were explicitly mentioned as being Celts by several classic authors (e.g. Strabo). Cf. the following map:

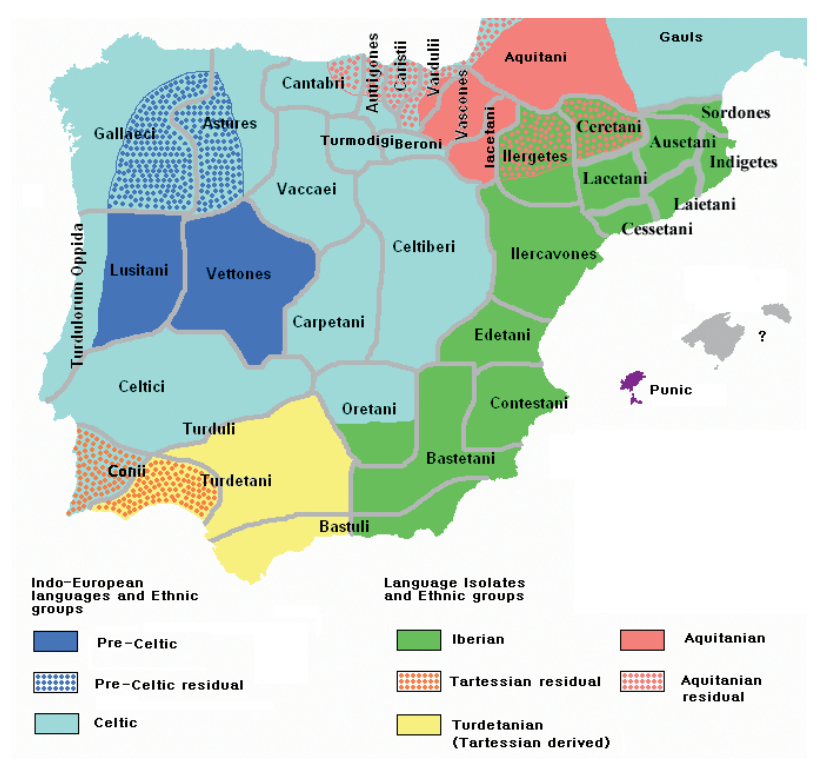

Figure 4: Author: Luís Fraga: Ethnology of the Iberian Peninsula c. 200 BC (retrieved February 25, 2021, from https://commons.wikimedia.org/wiki/File:Ethnographic_ Iberia_200_BCE.PNG)

27 As Frontinus (Strateg. III, 11, 4) relates, Viriatus took the people from Segobriga by surprise while they were occupied celebrating sacrifices (Sopeña 2005: 359). 
It is noteworthy that in Spain some of the most characteristic series of place names known from other Celtic areas of Ancient Europe are almost completely lacking, namely lānum, magos, dūnom (Luján 2013: 104). But one finds place names on -briga 'hill'. They contain designations for abstract concepts like power, strong, force:

Nertobrig(a) 2x, Celtic Nerto- 'force, strength' in Celtiberia (El Cabezo Chinchón near La Almunia de Doña Godina, $45 \mathrm{~km}$ to the south-west of Zaragoza) and in the southern Celtici-area (Baetica) (= Valera la Vieja, in the Spanish province Badajoz, $3 \mathrm{~km}$ to the east of Fregenal de la Sierra)

Segobrig(a) 2x, Celtic Sego- 'superiority, strength', only 1 of the 2 is identified (ruins on the Cabeza del Griego near Saelices, $20 \mathrm{~km}$ to the south-east of Tarancon in the Spanish province Cuenca $)^{28}$

Such names appear also uncompounded:

Segontia 5x in Celtiberia, (1) Segontia Lanca (not safely located, at the Duero, south or west of Numantia); (2) Segontia (Sigüenza at the Henares river in the Spanish province Guadalajara; the modern name continues the ancient one; remains of a pre-Roman settlement were found on the Cerro de Villas Viejas (a hill), $3 \mathrm{~km}$ from the modern town. The modern town probably continues the Roman settlement to which the inhabitants were moved); ${ }^{29}$ (3) Segontia between Epila at the river Jalón and Zaragoza, possible in the Dehesa de Ganaderos, $15 \mathrm{~km}$ to the west of Zaragoza; (4) Segontia Paramica: exact location unclear (Spanish province Palencia or Valladolid); (5) a further Segontia Paramica: exact location unclear (Spanish province Álava); cf. Caer Seiont (Segontium) in Wales and the peoples' name Segontiaci in Britain, the inhabitants' name Segontilienses in the Gallia Narbonensis and another Segontiliensis in the Iberian Peninsula (not localized, [known from the Is. CIL 13, 8093 Bonn] Rectugenus Magilonis f[ilius] Segontilieses [sic] eques ala Longiniana)

Segovia 3x, in Celtiberia, in the south and in Portalegre in the West, (1) Segovia (modern Segovia in the Spanish province named Segovia); (2) Segovia: in the south, i. e. in the Roman province Baetica, not exactly localized; (3) Segovia in Portalegre (the hill Segóvia at the river Caia, $12 \mathrm{~km}$ to the north of Elvas)

Segisamunculum (Cerezo del Rio Tirón, Burgos, Castilla y León, España), Celtiberian with Latin suffix -culo-

Segisama 2x, in Celtiberia (with Celtic superlative suffix -isama), (1) Segisma Brasaca (not exactly localized, probably in the west of Celtiberia); (2) Segisama Iulia (not exactly localized)

28 Traces of settlement apparently do not go beyond the middle of the $1^{\text {st }}$ century BC. In addition, it is possible that the Romans founded this Segobriga and may have relocated Celtic populations from another place here - from the non-localized other Segobriga in Celtiberia (Wodtko orally).

29 The idea is that the pre-Roman Celtiberian city lays on a hill. The Romans, however, brought the Celts down from the hill, and settled in the river valley, as they were easier to control. Such "transfers" of settlements from fortified positions into a plane, etc. are more common (Wodtko orally). 
Segisamo (modern Sasasmón, $50 \mathrm{~km}$ to the north-west of Burgos in the Spanish province Burgos)

The simplicia suggest that the focus is on communicating ideological concepts rather than localization. As Dagmar Wodtko says, especially Segisama is a good example of the fact that the dream of superiority is decisive for the designation. Segalso appears in personal names such as Segilus (only as masculine personal name) and in the tribe's name Segusiavi, a Celtic tribe with three oppida (Essalois, Crêt-Chatelard, Jœuvre) which controlled the Liger (Loire). The root of Segusiavi could designate a race of dogs of Celtic origin (Schwab 2017: 357; Dottin 1920: 285), as the Greek author Flavius Arrianus, the so-called "Younger Xenophon", described this dog type (Canis segusius) in the $2^{\text {nd }}$ century AD in his book Kynegetikos; ${ }^{30} \mathrm{cf}$. in the Germanic rights Pactus Legis Salicae Tit. VI, 1 canis segusius magister and the loan words Old High German sius(i)o, siusi. But also the idea of victory, of strength, or of inaccessible place (Belloguet 1872: 384) can be behind all these designations. In any case, the popularity in the place name denomination with ${ }^{\star}$ Sego- has a pattern that goes beyond Continental Celtic; segont- appears also in Britain.

Thus, in compounds like Segobriga the focus is on the first constituent and not on the second constituent $\operatorname{brig}(a)$ 'hill'. Together with Nerto-, here arises the idea of "force" names.

Other ideological concepts appear in the oikonyms Contrebia 'Living together' $3 \mathrm{x}$ and in Veniaka 'kindness' 1x:

Contrebia Belaisca, Spanish province Zaragossa (ruins on the Cabezo de las Minas near Botorrita, $20 \mathrm{~km}$ to the south-west of Zaragoza); Contrebia Carbica, Spanish province Cuenca (= ruins of Foos de Bayona, near Villasviejas, $50 \mathrm{~km}$ to the south-west of the city Cuenca (in the province Cuenca); Contrebia Leucade, Spanish region La Rioja (ruins near Inestrillas)

Veniaka 'kindness', the Celtiberian place is not localized; but cf. the inhabitant name vicani Venienses (epigraphically, near Meimoa in the Portugese province Castelo Branco)

Both oikonyms express ideals on a social level; for Veniaka cf. the personal name Gaulish Veni-carus, the ethnonym Ven-eti (Vanne) (Old High German wini 'friend').

Also religious concepts are encoded with compounds on -briga:

Deobriga 2x, (1) Deobriga (Arce Mirapérez, $4 \mathrm{~km}$ to the east of Miranda de Ebro, province Burgos, at the estuary of the river Zadorra into the Ebro); (2) Deobriga: exact location unknown, probably in the modern province Salamanca or Cáceres

Nemetobriga 2x in the West, (1) Nemetobriga in Galicien (Santa María de Trives or alternatively Trives Vieja near La Puebla de Trives, $50 \mathrm{~km}$ to the east of Ourense);

30 The Segusiani settled on the slopes of the Cottian Alps in today's départements Rhone and Loire, so to Lyon (Lugdunum). 
(2) Nemetobriga ebenfalls in Galicien exact location unknown, probably near Xinzo de Limia (province Ourense)

Religious concepts also play a major role in Romance and Germanic place names; cf. oikonyms like Santiago, Santa Fe, Saint-Germain-Source-Seine or St. Gallen. In these names no terms for 'church, monastery' are expressed.

Maybe the Gaulish-Latin name Boudobriga (Boppard) 'hill of victory' (D) also belongs in this context (Proto-Celtic *boudi- 'victory', Old Irish búaid 'win, gain', Middle Welsch budd 'gain, benefit']). In this case, the name should have been understood as 'there may always be a victory'. ${ }^{31}$

After all, such place names are examples for alternatives to a predominant spatial denomination strategy. They reflect a system of ratings and assessments of a social group.

\section{Conclusion}

After examining the etymology of mainly older oikonyms in the area of the Old European Hydronymy an answer to the questions asked at the beginning can be given: the expression of spatial relationships in oikonyms with water words is no universal. The ideologically determined oikonyms in Celtiberian speak against it. Other naming motifs also emerge in the Irish Dindsenchas. ${ }^{32}$ A proof of the non-universal character of the spatial designation of landscapes is also provided by Levinson (2008). His study of landscape designations in Yéli Dnye, the language of Rossel Island, a so-called Papuan (i.e. non-Austronesian) language in Papua New Guinea, shows that notions like 'mountain', 'river', 'cliff', 'valley', etc., which have been thought to be good candidates for universal concepts (Smith/Mark 2001), do not have direct counterparts. Common are rather designations after affordances and cultural beliefs.

However, because of the predominantly ideological designations of oikonyms in Celtiberia, a comment on the connection with the diffusion of the old European hydronymes is appropriate. While these names occur frequently in the Baltic area,

31 There are no testimonies for a victorious battle of the Gauls.

32 The denomination strategy of the Dindsenchas in the three versions $\left(9 \mathrm{t}^{\mathrm{h}}\right.$ to $12^{\text {th }} \mathrm{c}$.) is completely different. It is a collection of legends that served to explain place names. Though the word is composed of dind 'hill' and senchas 'handed down knowledge', it does not only refer to the elevations designated by dind, but also to any place from which a story has been passed down. However, the etymology of many place names is highly unlikely for linguistic or factual reasons. The legends quoted are only partly based on local oral tradition and in many cases depend on medieval scholarly speculation (Maier 1994: 98f.). The transparent field name Áth Froích 'ford of the heather' is an example. The name is explained by the death of a man named 'Heather' in this ford. The "reason" of the Dindshenchas lies in the fact that at each ford some uninteresting plant grows and therefore no naming motive results from it. For the place to get a name, something more must happen. 
possibly due to the favorable documentary situation, they capture Galicia in the northwest of the Iberian Peninsula. An example with the already mentioned word for 'alder' is Alesancia, a tributary of the Eo, whose estuary forms the boundary between the regions of Galicia and Asturias:

a. 775 Alesancia '(river) with alders' (tributary of the Eo, Cantábrico, LU); a. 371 Alisontia (Ausonius, Mosella), 8., 9., 10. Jh. Alsantia, Alsentia, Alsuntia (Luxemburg) (derivation from ${ }^{\star}$ alis $\bar{a}<{ }^{\star} h_{1 / 3}$ alisah 'white tree' or ${ }^{\star} h_{1}$ elisah ${ }_{2}$ 'red tree' (Middle Low Dutch else, Old High German elira 'alder' [Schaffner 2001: 384; Bichlmeier 2009[2011]: 191-193]) with river name suffix *-antiā ; cf. Aguence, Aguianca (tributary of the Miño, the longest river in Galicia, sharing the border with Portugal) ( ${ }^{\star} a k^{w}$-antin $\bar{a}$; Latin aqua [Moralejo 2005: 843-846])

As mentioned, however, the Celtiberians were inhabitants of the central-eastern Iberian region. The denomination system according to the Old European Hydronymy with its analogical dissemination and further development of dehydronymic derivations especially with $a$-vocalism, a spread that may be motivated by the sacred nature of rivers (Búa 2009; cf. Wodtko 2011: 215-218) apparently did not reach the speakers there. Perhaps also the widespread denomination of oikonyms according to spatial knowledge in the Hydronymy area has not arrived with them. In any case, the Celtiberians have instead favored a denomination system based on ideological knowledge. Landscape designations did not seem to matter.

\section{Bibliography}

ALEW = Hock, Wolfgang, et al. (2015): Altlitauisches etymologisches Wörterbuch. Vol. 1:2. Hamburg: Baar-Verlag.

Becker, Angelika (1994): Lokalisierungsausdrücke im Sprachvergleich. Eine lexikalisch-semantische Analyse von Lokalisierungsausdrücken im Deutschen, Englischen, Französischen und Türkischen.Tübingen: Niemeyer.

Becker, Angelika/Carroll, Mary (1997): The acquisition of spatial relations in a second language. Amsterdam: John Benjamins.

Belloguet, Dominique Roget de (1872): Ethnogénie gauloise. Paris: Maisonneuve et Cie.

Bichlmeier, Harald (2009[2010]): Arelape, Tergolape, Interlaken. Ein Beitrag zur keltischen Flussund Ortsnamenschicht im Alpenraum. In: Zeitschrift für historische Sprachforschung 122, 254-267.

Bichlmeier, Harald (2009a[2010a]: Bairisch-österreichische Orts- und Gewässernamen aus indogermanistischer Sicht. In: Blätter für oberdeutsche Namenforschung 46, 3-63.

Bichlmeier, Harald (2009[2011]): Einige grundsätzliche Überlegungen zum Verhältnis von Indogermanistik und voreinzelsprachlicher resp. alteuropäischer Namenkunde mit einigen Fallbeispielen (Moderne Indogermanistik vs. traditionelle Namenkunde, Teil 1). In: Namenkundliche Informationen 95/96, 173-208.

Bichlmeier, Harald (2012): Anmerkungen zum terminologischen Problem der 'alteuropäischen Hydronymie' samt indogermanistischen Ergänzungen zum Namen der Elbe. In: Beiträge zur Namenforschung, NF 47:4, 365-395. 
Bichlmeier, H. (2014/2016): Ammerbach und etymologisch Verwandtes. In: Österreichische Namenforschung 42, 22-34.

Bichlmeier, Harald (2015): Neue etymologische Vorschläge zu zwei Flussnamensippen der 'Alteuropäischen Hydronymie'. Elbe und Sinn, Shannon, San/Sjan, in: Krisch, Thomas/Niederreiter, Stefan (eds., unter redaktioneller Mitwirkung von Michael Crombach): Diachronie und Sprachvergleich. Beiträge aus der Arbeitsgruppe „historisch-vergleichende Sprachwissenschaft“ bei der 40. Österreichischen Linguistiktagung 2013 in Salzburg. Innsbruck: Institut für Sprachen und Literaturen der Universität Innsbruck, Bereich Sprachwissenschaft, 91-101.

Bichlmeier, Harald (2015[2016]: Ein neuer Blick auf die ältesten Orts- und Gewässernamen in (Mittel-)Europa. In: Namenkundliche Informationen 105/106, 299-331.

Bichlmeier, Harald (2016): Zur Widerspiegelung naturräumlicher Gegebenheiten in ,alteuropäischen “ Hydronymen - Neubewertungen althergebrachter Etymologien (Moderne Indogermanistik vs. traditionelle Namenkunde, Teil 5). In: Hough, Carole/Izdebska, Daria (eds.): Names and their Environment. Proceedings of the XXV. International Conference of Onomastic Sciences, Glasgow, 25-29 August 2014. Vol. 1: Keynote Lectures. Toponomastics I. Glasgow: University of Glasgow, 80-92.

Bichlmeier, Harald (2016a): Zur Etymologie des Flussnamens Laaber. In: Zeitschrift für celtische Philologie 63, 1-12.

Bichlmeier, Harald (2017): Was kann man an lexikalischen und morphologischen Elementen aus dem Namenschatz der sogenannten ,alteuropäischen Hydronymie' gewinnen? - Ein Zwischenbericht. In: Sandgaard Hansen, et al. (eds.): Etymology and the European lexicon. Proceedings of the 14th Fachtagung der Indogermanischen Gesellschaft, 17-22 September 2012, Copenhagen. Wiesbaden: Reichert, 37-52.

Bichlmeier, Harald (2018): Eine Präzisierung zur Etymologie der Namen der Ammer und der Amper. In: Blätter für oberdeutsche Namenforschung 55, 9-14.

Blažienė, Grasilda (2006): Zu den altpreussischen dehyronymischen Oikonymen. In: Indogermanische Forschungen 111, 305-319.

Búa, Carlos (2009) Teonimia e hidronimia. In: Kremer, Dieter (ed.): Onomástica galega Il: onimia e onomástica prerromana e a situación lingïstica do noroeste peninsular; actas do segundo Coloquio de Leipzig, 17 e 18 de outubro de 2008. Santiago de Compostela: Universidade de Santiago de Compostela, 91-155.

Casaretto, Antje (2004): Nominale Wortbildung der gotischen Sprache. Die Derivation der Substantive. Heidelberg: Winter.

Chuang, Shih-Yu (2010): Sprache und Sprachverwendung am Beispiel der Raumreferenz. Eine vergleichende Studie zwischen dem Chinesischen und dem Deutschen. Phil. Diss. Mannheim.

Delamarre, Xavier (2003): Dictionnaire de la langue gauloise. Une approche linguistique du vieuxceltique continental. Paris: Éditions Errance.

Delamarre, Xavier (2012): Noms de lieux celtiques de l'Europe ancienne (-500/+500). Arles: Éditions Errance.

Dottin, Georges (1920): La langue gauloise. Grammaire, textes et glossaire. Paris: C. Klincksieck. Echterhoff, Gerald (2004): Das Außen des Erinnerns. Was vermittelt individuelles und kollektives Gedächtnis? In: Erll, Astrid/Nünning, Ansgar (eds.): Medien des kollektiven Gedächtnisses. Konstruktivität, Historizität, Kulturspezifität. Berlin/New York: de Gruyter, 61-82. EDPC = Matasović, Ranko (2009): Etymological dictionary of Proto-Celtic. Leiden/Boston: Brill. EDPG = Kroonen, Guus (2013): Etymological dictionary of Proto-German. Leiden/Boston: Brill. EWA = Lloyd, Albert L./Lühr, Rosemarie (1988-2017) (eds.): Etymologisches Wörterbuch des Althochdeutschen. Vol. 1-6. Göttingen: Vandenhoeck \& Ruprecht.

García Alonso, Juan Luis (2001): The place names of ancient Hispania and its linguistic layers. In: Studia Celtica 35, 213-244. 
Gerullis, Georg (1922): Die altpreußischen Ortsnamen. Berlin/Leipzig: Vereinigung wissenschaftlicher Verleger.

Greule, Albrecht (2014): Deutsches Gewässernamenbuch. Etymologie der Gewässernamen und der zugehörigen Gebiets-, Siedlungs- und Flurnamen. Berlin/Boston: de Gruyter.

Gros, Adolphe (1935): Dictionnaire étymologique des noms de lieu de la Savoie. Belley: Aimé Chaduc.

Hoffmann, Karl (1957): Ein grundsprachliches Possessivsuffix. In: Münchener Studien zur Sprachwissenschaft 6, 35-40.

Jochum-Godglück, Christa (1995): Die orientierten Siedlungsnamen auf-heim, -hausen, -hofen und -dorf im frühdeutschen Sprachraum und ihr Verhältnis zur fränkischen Fiskalorganisation. Frankfurt am Main: Lang.

Katz, Hartmut (2003): Studien zu den älteren indoiranischen Lehnwörtern in den uralischen Sprachen. Aus dem Nachlaß hrsg. von Widmer, Paul/Widmer, Anna/Klumpp, Gersson. Heidelberg: Winter.

Knauff, Markus (1997): Räumliches Wissen und Gedächtnis. Wiesbaden: Deutscher Universitätsverlag. Krahe, Hans (1963): Die Struktur der alteuropäischen Hydronomie. Stuttgart: Franz Steiner.

Krahe, Hans (1964): Unsere ältesten Flußnamen. Wiesbaden: Harrassowitz.

Lacroix, Jacques (2007): Les noms d'origine Gauloise. La Gaule des dieux. Paris: Éditions Errance.

Lambert, Pierre Yve (1994): La langue gauloise. Paris: Éditions Errance.

Lehmann, Christian (2017): Kognitive und sprachliche Unterschiede in der Raumorientierung (http:// www.christianlehmann.eu/ling/lg_system/sem/raumorientierung 2.htlm). (Last access: 8.2.2019)

Levinson, Stephen C. (1996): Frames of reference and Molyneux's question. Crosslinguistic evidence. In: Bloom, Paul, et al. (eds.): Language and space. Cambridge, MA: The MIT Press, 109-169.

Levinson, Stephen C. (2003): Space in language and cognition. Explorations in cognitive diversity. Cambridge: Cambridge University Press.

Levinson, Stephen C. (2008): Landscape, seascape and the ontology of places on Rossel Island, Papua New Guinea. In: Language Sciences 30, 256-290.

Levinson, Stephen C./Wilkins, David P. (2006): Towards a semantic typology of spatial description. In: Levinson, Stephen C./Wilkins, David P. (eds.): Grammars of space. Explorations in cognitive diversity. Cambridge: Cambridge University Press, 512-552.

LIV = Rix, Helmut, et al. (2001): Lexikon der indogermanischen Verben. Wiesbaden: Reichert.

Löbner, Sebastian (1985): Definites. In: Journal of Semantics 4, 279-326.

Lühr, Rosemarie (2004): Lehnwörter im Althochdeutschen. In: Incontri linguistici 27, 107-120.

Luján, Eugenio (2013): Celtic and Celtiberian in the Iberian peninsula. In: Blasco, Eduardo, et al. (eds.): Iberia e Sardegna. Legami linguistici, archeologici e genetici dal Mesolitico all'Età del Bronzo. Firenze: Le Monnier, 97-112.

Maier, Bernhard (1994): Lexikon der keltischen Religion und Kultur. Stuttgart: Kröner.

Miller, George A./Johnson-Laird, Philipp N. (1976): Language and perception. Cambridge: Cambridge University Press.

Mills, Anthony David (1991). A dictionary of English place-names. Oxford: Oxford University Press.

Moralejo, Juan José (2005): Hidrónimos galaicos con sufijo -antia. In: Acta Paleohispanica IX. Paleohispanica 5, 837-860.

Nègre, Ernest (1959): Toponymie du Canton de Rabastens (Tarn). Paris: Ed. d’Artrey.

Nègre, Ernest (1990): Toponymie générale de la France. 1: Formations préceltiques, celtiques, romanes. Genève: Librairie Droz.

$\mathrm{NIL}=$ Wodtko, Dagmar S./Irslinger, Britta/Schneider, Carolin: Nomina im indogermanischen Lexikon. Heidelberg: Winter. 
ortsnamen.ch: https://www.ortsnamen.ch/.

Pèteraitis, Vilius (1997): Mažosios Lietuvos ir Tvankstos vietovardžiai. Ju kilmè ir reikšmė. Vilnius: Mokslo ir enciklopedijų leidybos institutas.

Rainer, Franz: (1993): Spanische Wortbildungslehre. Tübingen: Niemeyer.

Reitzenstein, Wolf-Armin von (2006): Lexikon bayerischer Ortsnamen. München: C. H. Beck.

Reitzenstein, Wolf-Armin von (2009): Lexikon fränkischer Ortsnamen. Herkunft und Bedeutung. Oberfranken, Mittelfranken, Unterfranken. München: C. H. Beck.

Schaffner, Stefan (2001): Das Vernersche Gesetz und der innerparadigmatische grammatische Wechsel des Urgermanischen im Nominalbereich. Innsbruck: Institut für Sprachen und Literaturen der Universität Innsbruck.

Schaffner, Stefan (2015): Zu den altkeltischen Flussnamen mit $n$-Suffix. In: Anreiter, Peter/ Weinberger, Helmut (eds.): Tagungsakten des internationalen namenkundlichen Symposiums in Kals am Großglockner (12.-15. Juni 2014). Wien: Praesens Verlag, 212-264.

Sims-Williams, Patrick (2006): Ancient Celtic place-names in Europe and Asia Minor. Oxford/Malden: Blackwell.

Sopeña, Gabriel (2005): Celtiberian ideologies and religion. In: Journal of interdisciplinary Celtic studies 6: The Celts in the Iberian Peninsula. e-Keltoi, 347-410.

Schwab, Vinzenz (2017): Volkssprachige Wörter in Pactus und Lex Alamannorum. Bamberg: University of Bamberg Press.

Smith, Barry/Mark, David M. (1999): Ontology with human subjects testing. An empirical investigation of geographic categories. In: American journal of economics and sociology 58:2, 245-272.

Smith, Barry/Mark, David M. (2001): Geographical categories. An ontological investigation. In: International journal of geographical information science 15:7, 591-612.

Smith, Barry/Mark, David M. (2003): Do mountains exist? Towards an ontology of landforms. In: Environment and Planning B: Planning and Design 30:3, 411-427.

Sommerfeld, Aloys (1971): Das altpreußische Wort „pannean“ in ostpreußischen Flurnamen. In: Zeitschrift für die Geschichte und Altertumskunde Ermlands 75, 143-149.

Strandberg, Svante (2016): River names. In: Hough, Carole (ed.): The Oxford handbook of names and naming. Oxford: Oxford University Press.

Talmy, Leonard (1983): How language structures space. Theory, research, and application. In: Pick, Herbert L./Acredolo, Linda P. (eds.): Spatial orientation. New York: Plenum Press, 225-282.

Tulving, Endel (1972): Episodic and semantic memory. In: Tulving, Endel/Donaldson, Wayne (eds.): Organization of memory. New York: Academic Press.

Udolph, Jürgen (1991): Die Ortsnamen auf -ithi. In: Eichler, Ernst (ed.): Probleme der älteren Namenschichten. Leipziger Symposion, 21.-22. November 1989. Heidelberg: Winter, 85-145.

Wagner, Norbert (2008): Pernopah und Ohsnofurt. Zur Synkope von Mittelvokalen nach langer Silbe. In: Beiträge zur Namenforschung NF 43:2, 167-171.

Wodtko, Dagmar (2011): Besprechung von Búa 2009. In: Namenkundliche Informationen 2011, 215-220. 